\title{
A Pediatric Case of Disseminated Lichen Sclerosus - a Case Report
}

\author{
Gjorgji GOCEV, Suzana NIKOLOVSKA and Ivana DOHCHEVA-KARAJOVANOV
}

University Clinic of Dermatology, Medical Faculty, Skopje, Macedonia

Correspondence: Gjorgji Gocev, E-mail: dr.gocev@t.mk

UDC 616.516-004:615.357

\begin{abstract}
Lichen sclerosus (LS) is an uncommon chronic inflammatory skin disorder with a predilection for the anogenital area, characterized by porcelain white papules, plaques and atrophic patches. We report a prepubertal, 12-year-old girl who presented with chronic, disseminated pearly, flat-topped papules, plaques and atrophic patches located on the trunk, limbs and in the anogenital area, consistent with LS based on clinical and histologic findings. Potent and ultrapotent topical corticosteroids should be considered as first-line treatment. The ultraviolet A1 (UVA1) and calcipotriol for extragenital lesions, as well as calcineurin inhibitors for anogenital lesions, are other treatment options for pediatric LS.
\end{abstract}

Key words: Lichen Sclerosus et Atrophicus; Vulvar Lichen Sclerosus; Child; Diagnosis; Clobetasol; Skin Diseases; Treatment Outcome; Signs and Symptoms

Lichen sclerosus is an uncommon chronic inflammatory skin disorder with a predilection for the anogenital area, characterized by porcelain white papules, plaques or atrophic patches. It was first described in 1887, by Hallopeau. Since then, many synonyms have been in use, notably 'guttate scleroderma,' 'white spot disease,' 'dermatitis lichenoides chronica atrophicans" or Csillag's disease,' 'kraurosis vulvae,' 'vulvar dystrophy, 'balanitis xerotica obliterans', 'lichen albus or Von Zumbusch Disease', or 'lichen sclerosus et atrophicus'. Since not all cases of LS et atrophicus exhibit atrophic tissue, 'et atrophicus' was dropped and replaced by 'lichen sclerosus,' which is now used for genital and extragenital lesions (1). LS is mostly seen in females with two peak ages of presentation: prepubertal girls and postmenopausal women. The prevalence rate of vulvar LS ranges between 1:70 to $1: 1000$ in women and 1:900 in children $(2,3)$.

The patogenesis of LS has not yet been completly elucidatet; however, genetic factors and autoimmunity have been implicated. The most common autoimmune diseases associated with LS were autoimmune thyroiditis (12 $\%)$, alopecia areata $(9 \%)$, vitiligo $(6 \%)$, and pernicious anemia $(2 \%)(4,5)$. Hormonal, environ- mental, and infectious factors have also been implicated as possible causes of this disease. Initially, the lesions are pearly, flat-topped papules that coalesce into plaques, over time becoming atrophic patches. Telangiectasias, follicular plugging and bullous lesions may also be seen. The most common location is the anogenital area, although extragenital lesions can be present, mostly affecting buttocks, breasts, submammary area, neck, back, chest, axillae and wrists. Oral mucosal involvement has also been reported. Extragenital lesions are rare, especially in children.

We report a prepubertal female child with LS with genital and disseminated extragenital lesions.

\section{Case Report}

A 12-year-old prepubertal girl with a 12-month history of numerous mildly pruritic hypochromic lesions distributed on the trunk, limbs, and genital area was referred to the University Clinic of Dermatology, Skopje, Macedonia. She had visited several physicians due to these complaints which were misdiagnosed as vitiligo, tinea, psoriasis and verrucae planae. She used various ointments such as 

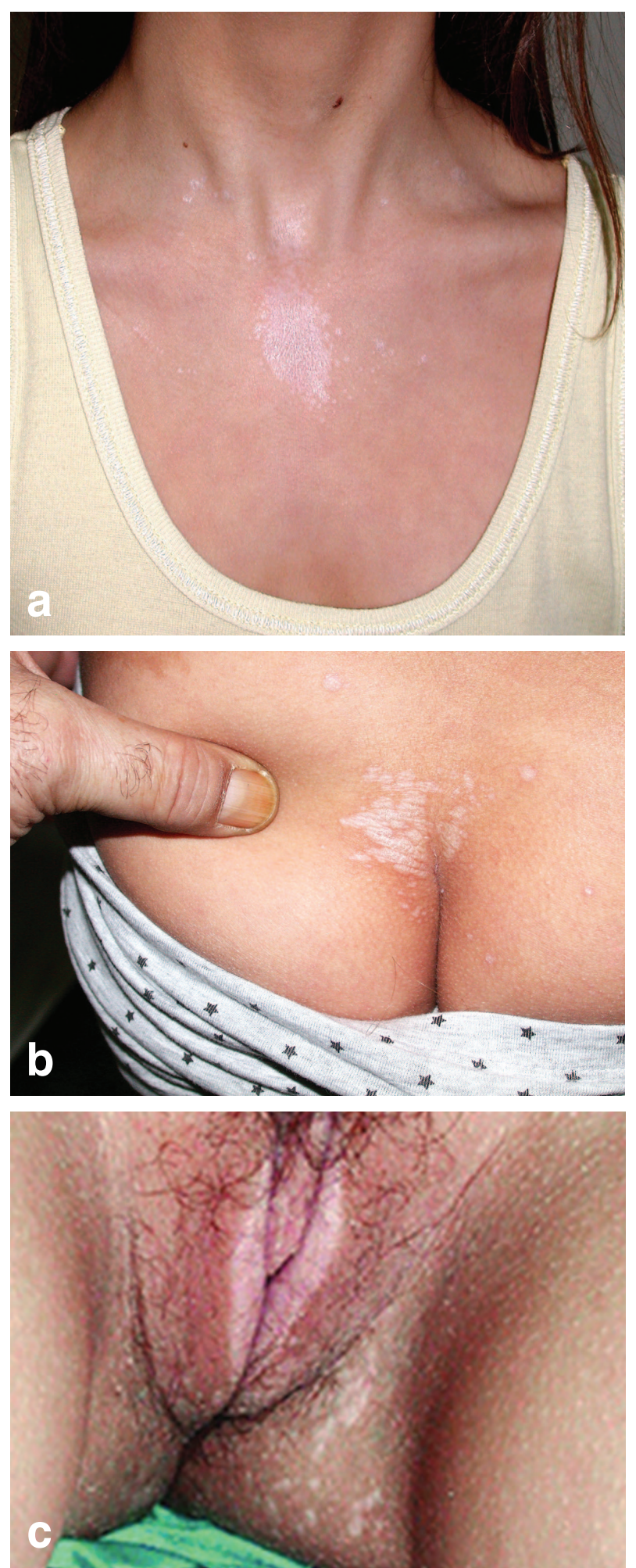

Figures 1a, 1b, 1c. White, shiny atrophic plaques located on the chest and sacral region. Hypochromic plaques seen on the labia majora ketoconazole, betamethasone, salicylic acid and crytherapy with liquid nitrogen. However, the lesions did not disappear. Her past medical history was unremarkable. Dermatological examination revealed numerous pearly-white papules distributed on the trunk and predominantly on the extensor surfaces of the extremities (Figures 2a and 2b). Some of the papules had depressed centers, while the others presented with whitish thickened surface. In some areas, they formed larger plaques (Figures 1a and $1 \mathrm{~b}$ ) and linear lesions, showing the Koebner phenomenon (Figure 2c). In the genital area, papules coalesced into hypochromic plaques seen on the labia majora, clitoris and intergluteal cleft (Figure 1c). Although the clinical picture was highly diagnostic, a biopsy of the non-treated older lesion was obtained (6). Histopathological examination showed hyperkeratosis, follicular plugging, basal layer rectification, epidermal atrophy, edema in the papillary dermis, perivascular lymphocytic infiltrate in the reticular dermis and loss of elastic fibers, feature that is typical for LS and not found in scleroderma. (Figures $3 a$ and $3 b$ ). Routine laboratory tests results, screening for associated autoimmune diseases with an autoantibody screening, and the thyroid status, were negative. According to the clinical and histological findings, a diagnose of disseminated LS was made. Topical clobetasol propionate $0.05 \%$ cream was applied twice daily for a month. She was adviced to use silk underwear to reduce physical trauma by clothing. On the first follow-up, the lesions were improved and the itching reduced. The application frequency of clobetasol propionate was reduced to once daily in the following two months, but the patient missed her next follow up visit, and since then she was not seen in our office.

\section{Discussion}

The exact prevalence of LS is unknown. However, the suspected prevalence in children is estimated to be $0.1 \%$. The disseminated, extragenital form of LS is poorly described in literature and accounts for 15 to $20 \%$ of cases. Only $6 \%$ of affected children have pure extragenital LS (7). The diagnosis of LS in children is often delayed, with avarage duration until diagnosis of 1 to 1.6 years (8). The patient in this report belongs to the small group of pediatric patients with extra- 
genital lesions with a 12-month delay until the correct diagnosis. It was misdiagnosed as vitiligo, psoriasis, tinea and verrucae planae. The main differential diagnosis of the genital lesions are vitiligo and sexual abuse if ecchymosis and petechial foci are present in the genital region.

Our patient presented with clinical symptoms typical for extragenital LS, including polygonal, ivory white, slightly elevated papules and plaques formed by a coalescence of papules, some of them with surface atrophy. The lesions were prone to koebnerization and appeared in the areas of physical trauma or continuous pressure. Some lesions showed prominent follicular plugging. A biopsy was obtained from a fully formed, non-treated lesion from the forearm and a specific histological pattern of LS was found: hyperkeratosis, epidermal atrophy with flattening of the rete ridges, vacuolar interface changes, loss of elastic fibers, and marked dermal edema with perivascular lymphocytic infiltrate. Thus, the final diagnosis of LS was made due to this positive clinicopathologic correlation.

The cause of LS remains unknown. According to the literature, $6.6 \%$ of prepubertal girls with anogenital LS present with an associated autoimmune disease (vitiligo and alopecia areata), and $56 \%$ of their parents or grandparents also suffer from LS (9). Immunogenetic studies have demonstrated a significant association with the HLA class II anti- gen DQ7 in $66 \%$ of female children (9). In our case, there was no association between LS and autoimmune diseases or any family cases.

Topical corticosteroids are highly effective, and remain the first-line treatment for LS. Topical clobetasol propionate is the gold standard in the treatment of vulval LS in women and girls (10). Long-term use of either very potent or moderate topical corticosteroids appears to be effective and safe (11). Our patient was treated with topical clobetasol propionate cream for three months. After the relief of symptoms and partial improvement of skin lesions, tapering of clobetasol propionate was recommended. Phototherapy is effective in patients with extragenital, disseminated LS. Among different UV regimens, UVA1 phototherapy is a potential first-line treatment option for extragenital LS (12). Other topical treatment modalities, such as tacrolimus and pimecrolimus for anogenital, and calcipotriol for extragenital LS, are found to be both effective and safe for long-term use (13). They are recommended for long-term application and for maintenance of the remission after initial treatment with clobetasol propionate (10). The clinical course of LS is variable. It is usually chronic, especially in women and girls, although the incidence of spontaneous remission in girls in puberty is estimated at $25 \%$ (14). However, one should not forget the intrinsic potential of the disease for development of squamous cell carcinoma (SCC) as a
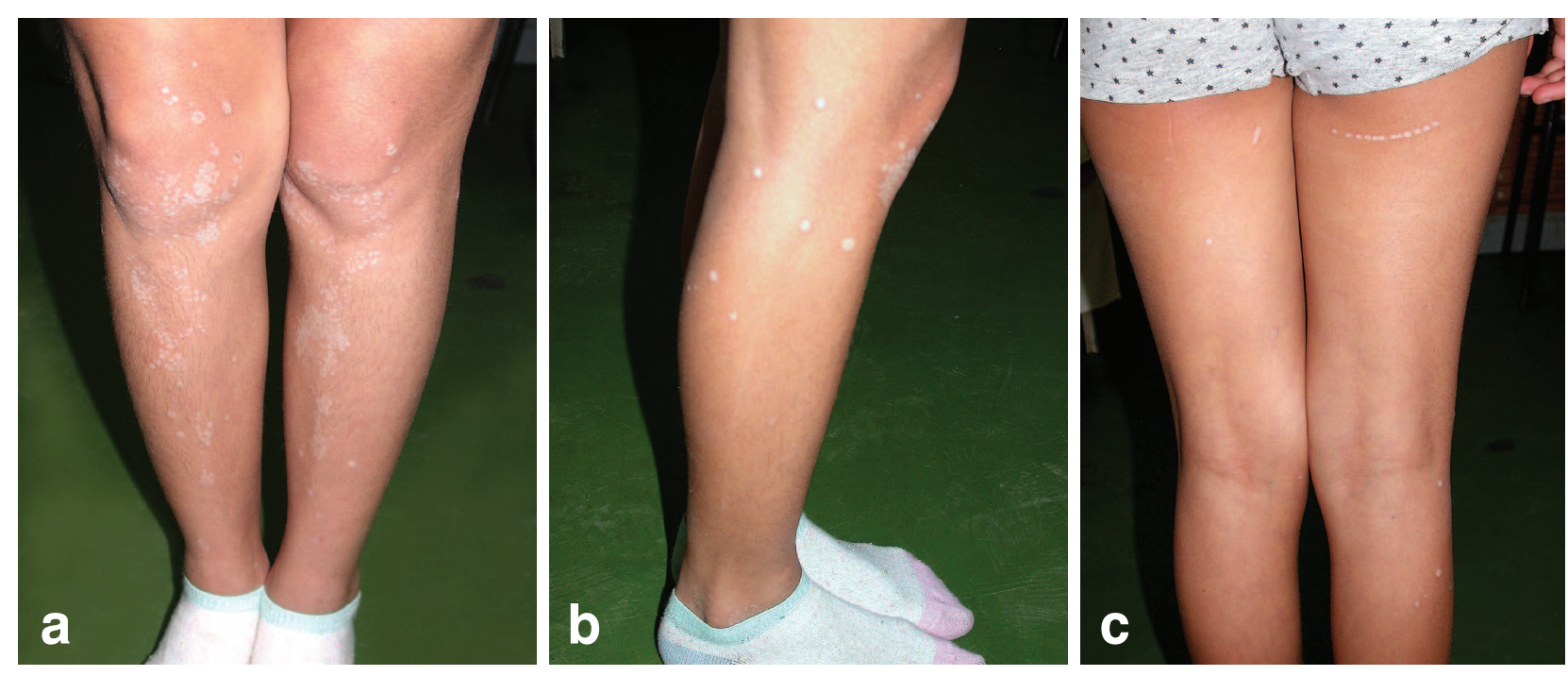

Figures 2a, 2b, 2c. Characteristic pearly-white, polygonal, slightly elevated papules coalescing into plaques on the lower extremities. Linear lesion showing the Koebner phenomenon on the right thigh 


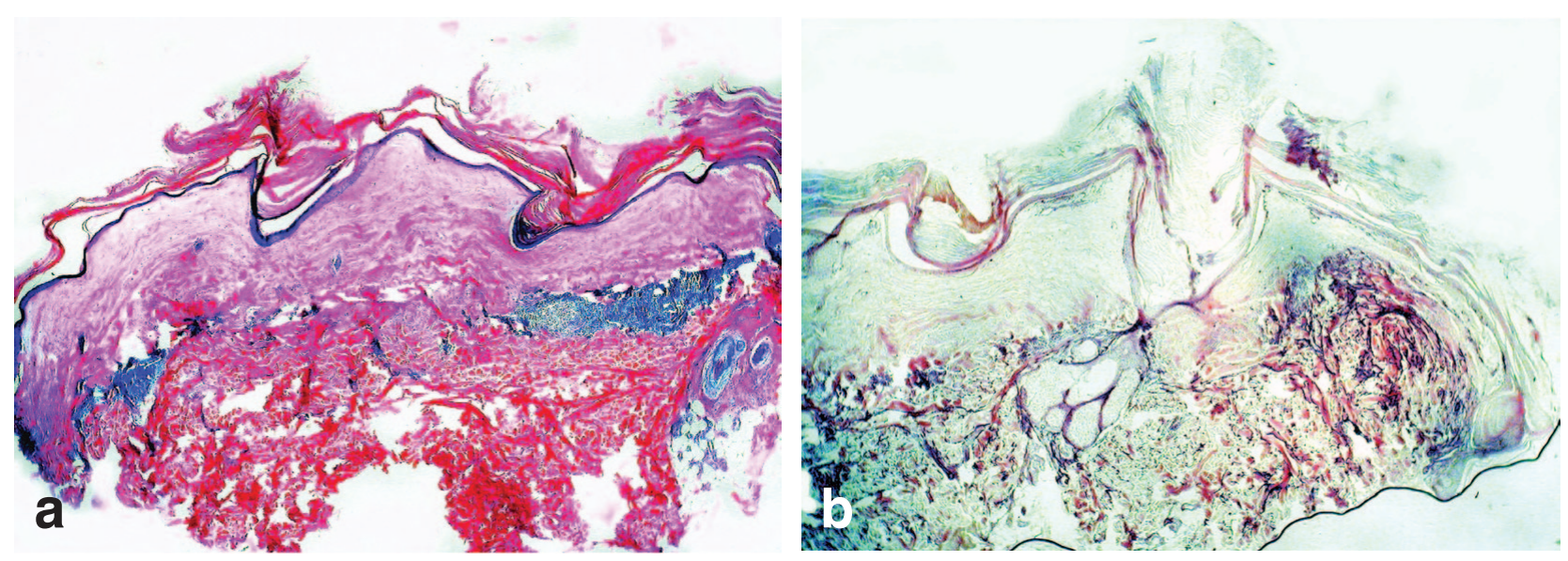

Figures 3a, 3b. Hyperkeratosis in the epidermis, follicular plugging, flattening of the rete ridges, vacuolar disruption in the basal layer, epidermal atrophy, extensive edema in the papillary dermis and erivascular lymphocytic infiltrate in the reticular dermis (H\&E staining $x 40$ ); Loss of elastic fibers in the upper dermis (Orcein staining X 40)

result of chronic inflammation. The development of indurated plaques or nodes and ulcers that do not heal indicate a malignant transformation.

\section{Conclusion}

Our case report of a female child with disseminated extra-genital lesions and discrete genital lesions illustrates a rare clinical presentation of LS. Taking into account that the disease in women may be associated with development of vulvar SCC, long-term followup should be recommended to all prepubertal girls with vulvar LS.

\section{References}

1. Friedrich EG. Lichen sclerosus. J Reprod Med. 1976;17(3):147-54.

2. Goldstein AT, Marinoff SC, Christopher K, Srodon $M$. Prevalence of vulvar lichen sclerosus in a general gynecology practice. J Reprod Med. 2005;50(7):477-80.

3. Powell J, Wojnarowska F. Childhoood vulvar lichen sclerosus: an increasingly common problem. J Am Acad Dermatol. 2001;44(5):803-6.

4. Cooper SM, Ali I, Baldo M, Wojnarowska F. The association of lichen sclerosus and erosive lichen planus of the vulva with autoimmune disease: a case-control study. Arch Dermatol. 2008;144(11):1432-5.

5. Sherman V, McPherson T, Baldo M, Salim A, Gao $\mathrm{XH}$, Wojnarowska $\mathrm{F}$. The high rate of familial lichen sclerosus suggests a genetic contribution: an ob- servational cohort study. J Eur Acad Dermatol Venereol. 2010;24(9):1031-4.

6. Niamh L, Naveen S, Hazel B. Diagnosis of voulval inflammatory dermatoses: a pathological study with clinica‥ correlation. Int J Gynecol Pathol. 2009;28(6):554-8.

7. Smith SD, Fischer G. Paediatric vulval lichen scleros

8. Ellis E, Fischer G. Prepuberal-onset vulvar lichen sclerosus: the importance of maintenance therapy

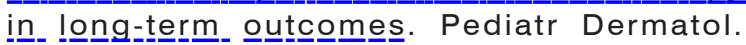
2015;32(4):461-7.

9. Powell J, Wojnarowska F, Winsey S, Marren P, Welsh K. Lichen sclerosus premenarche: autoimmunity and immunogenetics. Br J Dermatol. 2000;142(3):481-4.

10. Kirtschig G, Becker K, Günthert A, Jasaitiene D, Cooper S, Chi CC, et al. Evidence-based (S3) Guideline on (anogenital) lichen sclerosus. J Eur Acad Dermatol Venereol. 2015;29(10):e1-43.

11. Chi CC, Kirtschig G, Baldo M, Lewis F, Wang SH, Wojnarowska F. Systematic review and meta-analysis of randomized controlled trials on topical interventions for genital lichen sclerosus. J Am Acad Dermatol. 2012;67(2):305-12.

12. Kreuter $A$, Jansen $T$, Stücker M, Herde M, Hoffmann $\mathrm{K}$, Altmeyer $\mathrm{P}$, et al. Low-dose ultraviolet-A1 phototherapy for lichen sclerosus et atrophicus. Clin Exp Dermatol. 2001;26(1):30-2.

13. Goldstein AT, Creasey A, Pfau R, Phillips D, Burrows LJ. A double-blind, randomized controlled trial of clobetasol versus pimecrolimus in patients with vulvar lichen sclerosus. J Am Acad Dermatol. 2011;64(6):e99-104.

14. Powell J, Wojnarowska F. Childhood vulvar lichen sclerosus. The course after puberty. J Reprod Med. 2002; 47(9):706-9. 


\section{Diseminovani Lichen Sclerosus u dečjem uzrastu - prikaz slučaja}

\section{Sažetak \\ Lichen sclerosus (LS) predstavlja retku, hroničnu in- flamatornu dermatozu, lokalizovanu uglavnom u ano- genitalnoj regiji, za koju je karakteristična pojava porcelanskobeličastih papula, plakova ili atrofičnih makula. $U$ radu je prikazana devojčica u prepubertet- skom uzrastu - 12 godina, sa kliničkim nalazom hroničnih, diseminovanih, ravnih papula, plakova $\mathrm{i}$ atrofičnim makulama, distribuiranih po telu, ekstrem-}

\begin{abstract}
itetima i anogenitalnoj regiji. Klinički i histopatološki nalaz su karakteristični za LS. Potentne i ultrapotentne topijske kortikosteroide treba razmotriti kao lekove prve linije za lečenje LS. Ostale terapijske opcije, koje se mogu upotrebiti u pedijatrijskom uzrastu, uključuju UVA1 i kalcipotriol za ekstragenitalne lezije i inhibitore kalcineurina za anogenitalne promene.
\end{abstract}

Ključne reči: Lichen sclerosus et atrophicus; Vulvarni lichen sclerosus; Dete; Dijagnoza; Clobetasol; Kožne bolesti; Ishod terapije; Znaci i simptomi 